\title{
Serological Survey of Antibodies against Brucella Organisms in One Humped Camel (Camelus dromedarius) Herds in the Lake Chad Area of Borno State, North Eastern Nigeria.
}

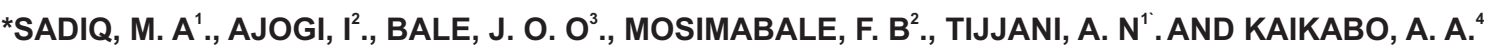

${ }^{1}$ Mohamet Lawan College of Agriculture, P. M. B. 1427, Maiduguri, Borno State Nigeria. ${ }^{2}$ Dept. of Veterinary Public Health and Preventive Medicine, Faculty of Veterinary Medicine, Ahmadu Bello University, Zaria, Nigeria. ${ }^{3}$ National Animal Production Research Institute (NAPRI), Shika Zaria, Nigeria. ${ }^{4}$ National Veterinary Research Institute (NVRI) Vom, Nigeria. ${ }^{*}$ Corresponding author: Email: sadiqwaves@yahoo.com

\section{SUMMARY \\ Sero-prevalence of brucellosis in the one-humped camel (Camelus dromedarius) was carried out in the Lake Chad area of Borno state. A total of two hundred and fifty four (254) sera samples collected from adult camels in herds located in the Lake Chad Area of Borno state, North eastern Nigeria, were tested using Rose Bengal Plate test (RBPT) and Microtitre Serum Agglutination Test (MSAT). Twenty four samples (9.4\%) were positive by both RBPT and MSAT, out of which $10(3.9 \%)$ and $14(5.5 \%)$ were males and female respectively. There was no statistically significant association between sex and positive serological reaction ( $P>0.05)$.}

KEY WORDS: Sero-prevalence; Brucellosis; Camels; Lake Chad; Nigeria

\section{INTRODUCTION}

Brucellosis is a zoonosis caused by non-motile aerobic gram negative coccobacilli, which is transmitted to the human population mostly as an occupational disease or through the ingestion of raw cattle, goat or sheep ( including camel) milk and/or unpasteurized dairy products (Young, 1995). Camel husbandry is vital for numerous pastoralist groups in Africa and Asia (Abass and Agab, 2002; McDermott and Arimi, 2002). Camel herds are predominantly in the hands of pastoralist or agro-pastoralists relying on transhumance or nomadism moving along the arid and semi-arid zones crossing international boundaries (Farah, 2004; Abbas and Omer, 2005). The camel's ability to survive and produce under harsh environmental conditions has made it possible to use marginal and desertified ecosystems; and over the centuries, the camel has been a symbol of stability for the pastoralists in the arid zones of the world (Abbas et al., 1992). Camels are also believed to be a reservoir for brucellosis (Ismaily et al., 1988). The one-humped camel (Camelus dromedarius) may serve as a potential source of Brucella infection to other livestock and humans in Nigeria (Ajogi and Adamu, 1998). Risk factors for infection include: the handling of contaminated animal products such as unpasteurized milk, and milk products (including cow, goat and camel), meat ("Suya and Kilishi") (Bale, 1991), animal by-products and handling cultures of Brucella spp in laboratories (Ajogi and Adamu, 1998, Salari, 2002; FAO, 2003). Camel meat and milk is increasingly important as a source of protein for the human populace; this highlights the potential importance of camels as reservoir and source of brucellosis for humans (Kudi et al., 1997; Adamu and Ajogi, 1999). The initial report on prevalence of brucellosis among camels in Nigeria was based on serological evidence by Okoh (1979), where a prevalence rate of $1 \%$ was reported in slaughtered camels in Kano. Later a prevalence of $7.5 \%$ was found among camels in Kano by the use of MSAT (Kudi et al., 1997). Junaidu et al. (2006) carried out a sero-prevalence study of brucellosis in camels slaughtered in Sokoto State abattoir of Northwestern Nigeria. In that study, out of the 329 blood samples screened over a period of 52 weeks, $37(11.42 \%)$ were found to be positive by Rose Bengal Plate test (RBPT), serum agglutination test (SAT) and competitive enzyme linked immunosorbent assay (cELISA). Adamu et al. (1997) in studies on seroepidemiology of brucellosis in one-humped camel (Camelus dromedarius) from three northern states reported prevalence rates of $12.5 \%, 18.6 \%$ and $25.5 \%$ in Kano, Kaduna and Borno States respectively. Prevalence rates of 
9.5\% (Zaria et al., 1990) and 1.8\% (Egbe-Nwiyi et al., 1999) were reported in camels slaughtered in Maiduguri Borno state North-Eastern Nigeria. There was no evidence of work previously done in Nigeria to test the sero-prevalence of brucellosis in constantly migrating camel herds in the range. This study was designed to determining the sero-prevalence of brucellosis among nomadic migratory camel herds located in the Lake Chad Area of Borno state, North eastern Nigeria.

\section{MATERIALS AND METHODS}

Two hundred and fifty four (254) sera samples were collected from adult camels of both sexes in nomadic migratory herds located in the Lake Chad Area of Borno state, North eastern Nigeria between December, 2007 and February, 2008. Blood (5ml) was aseptically collected from jugular vein, using hypodermic syringe and needle; blood in the syringe was gently transferred into sterile plain bijou bottle, labelled and placed in a slanting position for one hour to get the serum separated from the clotted blood. Sera samples were stored at $-20^{\circ} \mathrm{C}$. The sera was examined for Brucella antibody by RBPT as described by OIE manual (2004) and MSAT as described by Alton et al. (1988). Sera samples with titre greater than 1:40 (30IU) are considered positive according to WHO (2006).

\section{RESULTS}

Out of the 254 sera samples collected from adult camels of both sexes, comprising of 89 males and 165 females, in herds located in the Lake Chad area, $24(9.4 \%)$ samples were positive by both RBPT and MSAT. Out of the positive samples, 10 (3.9\%) and $14(5.5 \%)$ males and females respectively were positive by both RBPT and MSAT (Table I). All samples tested positive to RBPT also tested positive to MSAT. There was no statistically significant association between sex of camels male with $\mathrm{OR}=1.324$ (95\% CI on $\mathrm{OR}=0.613-2.859$ ); female with $\mathrm{OR}=0.970$ $(95 \% \mathrm{CI}$ on $\mathrm{OR}=0.889-1.058)$ and serological reaction $(\mathrm{P}>0.05)$. The overall prevalence rate of brucellosis among camel herds in the Lake Chad area of Borno state was 9.4\%.
Table I: Sex distribution of the serological test (RBPT/MSAT) status of the camels tested.

\begin{tabular}{|c|c|c|c|c|c|c|c|}
\hline \multirow[b]{2}{*}{ Sex } & \multirow{2}{*}{$\begin{array}{l}\text { Total } \\
\text { Animals } \\
\text { tested }\end{array}$} & \multicolumn{2}{|c|}{ RBPT } & \multicolumn{2}{|c|}{ MSAT } & \multirow{2}{*}{\multicolumn{2}{|c|}{$\begin{array}{l}95 \% \mathrm{Cl} \text { on OR } \\
\text { Lower Upper }\end{array}$}} \\
\hline & & Positive & Negative & Positive & Negative & & \\
\hline Male & 89 & $10(3.9 \%)$ & 79 & $10(3.9 \%)$ & 79 & 1.324 & $0.613 \quad 2.859$ \\
\hline Female & 165 & $14(5.5 \%)$ & 151 & $14(5.5 \%)$ & 151 & 0.970 & $0.889 \quad 1.058$ \\
\hline Total & 254 & $24(9.4 \%)$ & 230 & $24(9.4 \%)$ & 230 & & \\
\hline
\end{tabular}

\section{DISCUSSION}

Brucellosis among camel herds in the range has not been studied extensively in Nigeria. Most of the previous studies were carried out on camels slaughtered in various abattoirs. The prevalence of $9.4 \%$ found in this study is lower than the report by Waghela et al. (1978) in a serological survey of brucellosis in North Eastern Province of Kenya, where the prevalence of $14 \%$ was found among camels tested for infection. Bitter (1986) examined 948 camels from different herds in eastern Sudan and reported a prevalence of 16.5-32.3\%. Musa (1995), who examined 416 camels from seven herds owned by nomads of the same clan in western Sudan, found 23.3\% prevalence and concluded that camels ranked second only to cattle in the rate of infection with brucellosis. In another study in Sudan, Musa et al. (2008) reported a prevalence of $28.3 \%$ in camels. Junaidu et al. (2006) in a seroprevalence study of brucellosis in camels slaughtered in Sokoto State abattoir of Northwestern Nigeria, found 37 (11.42\%) samples positive to Rose Bengal Plate test (RBPT), serum agglutination test (SAT) and competitive enzyme linked immunosorbent assay (cELISA). Adamu, et al. (1997) carried out a seroepidemiology of brucellosis in one-humped camel (Camelus dromedarius) in three northern states, reported prevalence rates of $12.5 \%$, $18.6 \%$ and $25.5 \%$ in Kano, Kaduna and Borno States respectively. The higher prevalence reported could be due to differences in camel population sampled and location. Another reason could be that most camels, especially the females, presented for slaughter are culled as a result of productive or reproductive failure which could be Brucella infected. The prevalence of $9.4 \%$ in this study was higher as compared with the findings of Gameel et al. (1993) in Libya who reported that the prevalence of $4.1 \%$, from sera of 967 camels of both sexes tested for antibodies to Brucella using the Rose Bengal 
plate test (RBPT), serum agglutination test (SAT) and the complement fixation test (CFT). Our findings was also higher as compared with the $1 \%$ reported among slaughtered camels in Kano by Okoh (1979) and 7.5\% by Kudi et al., (1997) out of 480 camels sampled in the same area. The prevalence of $9.5 \%$ by Zaria et al. (1990) was similar to our finding but a lower prevalence of 1.8 per cent (Egbe-Nwiyi et al., 1999) was reported in camels slaughtered in Maiduguri Borno state North-Eastern Nigeria. The variations in the prevalence could be due to difference in sample sources as those earlier studies were based on samples collected from camels slaughtered in various abattoirs, while our work was based on camel herds in the range. In this study there were more serologically positive reactors among the female camels than males, however not statistically significant, but this is in contrast with Agab (1993) and Yagoub et al. (1990) who reported that the seroprevalence of brucellosis was three to fourfolds higher among adult camels than young ones and two-folds higher in females compared to males. This finding also disagrees with the findings of Zaria et al. (1990); Egbe-Nwiyi et al. (1999); Kudi et al., (1997); Adamu, et al. (1997) and Junaidu et al. (2006) all of whom reported higher sero-prevalences of brucellosis among female camels than males.

In conclusion there should be officially coordinated control programme for brucellosis in livestock in Nigeria. More epidemiological investigations into brucellosis in camel herds in the range should be conducted to elucidate more risk factors associated with the disease.

\section{REFERENCE}

ABBAS, B. AND AGAB, H. (2002): A Review of Camel Brucellosis. Preventive Veterinary Medicine. 55(1)47-56.

ABBAS, B., CHABEUF, N., SAINT-MARTIN, G., BONNET, P., MILLAIRD, A., BASHIR, H., MUSA, B. E. (1992): Camel pastoralism in the Butana and northeastern Sudan, an interdisciplinary study. Nomadic Peoples 31, 64-84.

ADAMU, N. B. AND AJOGI, I. (1999): Serological investigation of camels (Camelu dromedaries) slaughtered at Kano municipal Abattoir for Evidence of Brucellosis. Tropical Veterinarian. 18: 45-48.

AGAB, H. (1993): Epidemiology of Camel Diseases in Eastern Sudan with Emphasis on Brucellosis: Unpublished M V Sc. Thesis, University of Khartoum, Faculty of Veterinary Science 184.
AJOGI, I. AND ADAMU, N. B. (1998): The one-humped camel: A potential source of Brucella infection to other livestock and man in Nigeria. Proceedings of silver anniversary conf. of NSAP held in Abeokuta march 21-28. 377-378.

ALTON, G. G. JONES, L. M., ANGUS, R. D. AND VERGER, J. M. (1988): Techniques for brucellosis laboratory, first edition, Institut National de la research Agronomique, Paris. 63-129.

BALE, J. O. O. (1991): Brucellosis: a threat to livestock production and human health in Nigeria. Contribution to a symposium in honour of Prof. Saka Nuru, National Animal Production Research Institute, (NAPRI), Zaria. 15-26.

BITTER, H. (1986): Disease resistance in Dromedaries with particular reference to Trypanosoma evansi infection. Inaugural Desertation. Tierarticliche Hochschedule, Hanover, Germany. Cited in: Abbas, B. and Agab, H. (2002): A Review of Camel Brucellosis. Preventive Veterinary Medicine. 55 (1) 47-56. 55 (1): 47-48

EGBE-NWIYI, T. N, AMEH, J. A, ZARIA, L. T AND YITA, A. B. (1999): Sero-prevalence of camel (camelus dromedarius) Brucellosis in semi Arid zones of North of North-Eastern Nigeria. Tropical Veterinarian. 17: 119-123.

FOOD AND AGRICULTURAL ORGANIZATION [FAO] (2003): Guidelines for coordinated human and animal Brucellosis surveillance. FAO Animal production and Health paper 156. 1-46. FAO, Rome. http://www.fao.org

GAMEEL, S. E. A. M. MOHAMED, S. O., MUSTAFA, A. A. AND AZWAI, S. M. (1993): Prevalence of camel brucellosis in Libya. Tropical Animal Health and Production. Volume 25(2) 91 - 93

ISMAILY, S. I. N., HARBY, H. A. M. AND NICOLETTI, P. (1988): Prevalence of brucella antibodies in four animal species in the Sultanate of Oman. Tropical Animal Health and Production. 20:269-271.

JUNAIDU, A. U. OBOEGBULEM, S. I. SHARUBUTU, G. H. AND DANEJI, A. I. (2006): Brucellosis in camels (Camelus dromedaries) slaughtered in Sokoto, northwestern Nigeria. Animal Production Reseach Advances. 2: (3).11-13.

KUDI, A. C., KALLA, D. J. U., KUDI, M. C.; KAPIO, G. I. (1997): Brucellosis in camels. Journal of Arid Environments, October, 37,(2), 413-417.

McDERMOTT, J. J. AND ARIMI, S. M. (2002): Brucellosis in Sub-Saharan Africa: Epidemiology, Control and Impact. Veterinary Microbiology. 90: 111-134.

MUSA M. T. (1995): Brucellosis in Darfur States: The magnitude of the problem and methods of diagnosis and control of the disease. PhD Thesis, University of Khartoum, Sudan, 83-96.

MUSA, M. T., EISA, M. Z. M., EL-SANOUSI, E. M., ABDEL WAHAB, M. B. AND PERRETT, L. (2008): Brucellosis in Camels (Camelus dromedarius) in Darfur, Western Sudan Journal of Comparative Pathology. Volume 138, 151-155.

OFFICE INTERNATIONAL DES EPIZOOTIES (OIE) (2004): Manual of Diagnostic Tests and Vaccines for Terrestrial Animals. http://www.oie.int/eng/hs 
OKOH A. E. J. (1979): A survey of brucellosis in camels in Kano, Nigeria. Tropical Animal Health and Production. 11: 231-314.

SALARI, M. H., (2002): Seropidemiology of brucellosis among animal farmers of yaze province. Iranian Journal of Public Health. 31, (1-2) . 29-32.

WAGHELA, S., FAZIL, M. A., GATHUMA, J. M., KAGUNYA, D. K., (1978): A serological survey of brucellosis in camels in northeastern province of Kenya. Tropical Animal Health and Production. 10: 28-29.

WORLD HEALTH ORGANIZATION (WHO) (2006): Brucellosis in Humans and Animals. Produced in Collaboration with Food and Agricultural Organization (FAO) and Office International des Epizootics (OIE). WHO/CDS/EPR/2006.7:1-102.
YAGOUB, I. A., MOHAMED, A. A., SALIM, M. O., (1990): Serological survey for Brucella abortus antibody prevalence in the one-humped camel (Camelus dromedarius) from eastern Sudan. Revue d Elevage et de Medecine Veterinaire des Pays Tropicaux. 43: 167-171

YOUNG E. J. (1995): Brucella species. In: Mandell GL, Bennett JE, Dolin R, eds. Mandell, Douglas and Bennett's principles and practice of infectious diseases. 4th Ed. New York: Churchill Livingstone: 2053-60.

ZARIA, L. T., EGWU, G. O., NAWATHE, D. R. and OJEAMIREN, M. E. (1990): A preliminary report on the sero-prevalence of Brucellosis in camels (Camelus dromederius) in Maiduguri. Zariya Veterinarian. 5: No.(1) 64-65. 